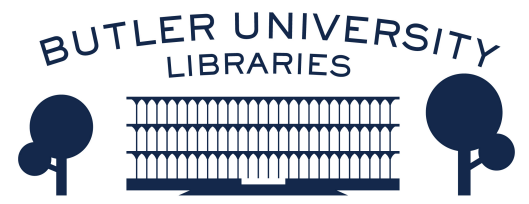

Journal of Hindu-Christian Studies

Volume 31 Celebrating Rāmānuja at 1000: The

Heritage and Promise of the Study of Rāmānuja

in a Christian-Hindu Comparative Theology

Article 36

2018

\title{
Book Review: Khrist Bhakta Movement: A Model for an Indian Church? Inculturation in the Area of Community Building
}

Kerry P.C. San Chirico

Villanova University

Follow this and additional works at: https://digitalcommons.butler.edu/jhcs

\section{Recommended Citation}

San Chirico, Kerry P.C. (2018) "Book Review: Khrist Bhakta Movement: A Model for an Indian Church? Inculturation in the Area of Community Building," Journal of Hindu-Christian Studies: Vol. 31, Article 36. Available at: https://doi.org/10.7825/2164-6279.1716

The Journal of Hindu-Christian Studies is a publication of the Society for Hindu-Christian Studies. The digital version is made available by Digital Commons @ Butler University. For questions about the Journal or the Society, please contact cbauman@butler.edu. For more information about Digital Commons @ Butler University, please contact digitalscholarship@butler.edu. 
"over," that is, conversion marked by a complete and transformative shift in identity from one community to another. This contention lies at the heart of Gandhi's assertion (and complaint, when speaking to Christian missionaries) that it was better to encourage a person to advance spiritually within their own tradition than to convert them to one's own. My sense, however, is that Indian Christians have in recent decades begun to think a bit more like Gandhi in this regard. As Kerry San Chirico and others have shown, for example, Yeshu bhakt (Devotees of Jesus) and Khrist bhakt (Devotees of Christ) movements have recently proliferated in India. In these movements, non-Christians are welcome to come and have a transformative spiritual encounter with Jesus like they might with any non-Christian deity, but, importantly, are not encouraged to convert in the sense of formally becoming christian. They are, in essence, encouraged to convert "up" but not "over." One finds this new way of thinking primarily among mainstream Catholic and Protestant Christians, however. The last place one would expect to find it is among Pentecostals, because Pentecostal theology has historically tended to encourage a complete rupture with the non-Christian past at the moment of conversion (the reality, of course, is always much messier). In light of this, one of Sahoo's most interesting discoveries is that even Pentecostal conceptions of conversion seem to be shifting, such as in the words of one of his interviewees, Madam Mary, who, according to Sahoo, "pointed out that real conversion is not about dharma parivartan (change of religion) or acceptance of Christian baptism; it is rather about jeevan parivartan or total transformation of life" (72). Whether this decreasing emphasis on a formal change of religious affiliation is a result of the influence of Hinduism or a response to the challenges that come with formal changes in religious affiliation (e.g., social resistance and hostility, a loss of reservation benefits) is a more difficult question to answer.

Pentecostalism and Politics of Conversion in India is the work of an intelligent and thoughtful interpreter with excellent scholarly instincts, a knack for lucid prose, and a very broad and wide-ranging grasp of the relevant scholarly literature. It is eminently readable and would be accessible even to an advanced undergraduate audience.

Chad Bauman

Butler University

\section{Khrist Bhakta Movement: A Model for an Indian Church? Inculturation in the Area of Community Building. By Ciril J. Kuttiyanikkal. Berlin: LIT Verlag, 2014, 377 pages.}

THE Khrist Bhaktas can be found in and around Roman Catholic spaces of the Banaras region. These "devotees of Christ" are mostly Scheduled Castes (SCs) and Other Backward Classes (OBCs). They are majority women, though male numbers are increasing. And they regularly seek the ministrations of Indian
Missionary Society (IMS) priests, nuns from various orders, and fellow Khrist Bhakta and lay Catholic aguas, or catechists, who travel to scores of local villages fanning out of Matri Dham Ashram like ripples on water. On the second Saturday of each month, thousands of Khrist Bhaktas can be found at the ashram 
worshiping Yesu, testifying to healings received from his Spirit, and seeking material and spiritual succor from those that comprise Indian Catholicism's devotional constellation. The plot twist: Because they are unbaptized, Khrist Bhaktas do not receive the sacraments accompanying a Catholic from cradle to grave. So in lieu of the sacraments various means have been enacted between bhaktas and clergy allowing for tangible encounters with a novel deity-in Kashi, of all places. The essentialized mind reels.

Mark Juergensmeyer once wrote that India is "good to think with." The same can be said of the Khrist Bhaktas, an anomalous community that this reviewer has himself been studying and (thinking with) since 2008. What are the Khrist Bhaktas? A hybrid HinduChristian religious movement in the making? A new form of charismatic Christianity in which devotees remain within their inherited family and jati? A Hindu movement with a surprising ishtadevata? The religious expression of on-going low caste emancipation? All are reasonable conclusions, but they are hardly academic due to complicating factors, some legal: due to Indian personal religious law, the Khrist Bhaktas are considered Hindu because they are identified with communities deemed not Christian, Muslim, or Parsi; but because they are unbaptized they can neither be considered Catholic by Catholic canon law (which requires baptism) nor Christian by terms set by the Indian constitution. Khrist Bhaktas thus dwell both in between and across religious boundaries. This would matter less in a country where particular religious and class identities are unidentified in favor of individual rights before the law. Yet in India, where such identities are explicit and legally defined, where different laws attend to different communities, and where affirmative action programs aid some and not others, it matters a great deal.

For Catholics in relationship with the Khrist Bhaktas, and to those sensitive to their existence, the community evokes certain challenges and evocations-regarding the nature of salvation and the Church's role in it, the way ecclesial structures are understood to inhibit mission (the view of many Indian clergy), the inability of a tradition to socially control meanings that originate from within its own history (e.g. baptism), and the concomitant vagaries of choosing to follow Yesu (for Khrist Bhaktas and Catholics) at a time when doing so can be, at least, complicated and, at most, dangerous.

Kuttiyanikkal's text, a doctoral dissertation written at the Tilburg School of Catholic Theology in the Netherlands, seeks to examine the Khrist Bhaktas to see whether they provide a model for being "the Church" in contemporary India. First, however, the scholar admirably provides necessary historical and theological context for answering the question in a sustained and systematic fashion. The Introduction sets the stage for the rest of the text, notes prior research, and attempts to identify criteria for determining "a successful inculturation in the area of community building" (34). This is both a descriptive and prescriptive work seeking to accomplish something on behalf of the Indian Catholic Church in the hope that it might contribute to the wider tradition, particularly as understood through the Second Vatican Council. For as IMS clergy often say, and as the author concurs, the Khrist Bhaktas represent "a new way of being the Church." Chapter 2 places the community within the context of Indian Catholic inculturation efforts, noting widespread (elite) Indian Catholic dissatisfaction with structures and practices that are often yoked to the popular (read 
Hindu) perception of Catholicism as foreign imposition attractive only to dalits. Chapter 3 explicates the history, organization, and function of the movement. Chapter 4 describes ashram and Khrist Bhakta practices and the negotiations made between devotees, priests, and nuns. These chapters present a necessary prolegomena to what must be considered the work's core as well as its primary contribution to Catholic thoughtthat is, Chapter 5 and the Conclusion.

In Chapter 5, "The Ecclesiology of the Khrist Bhakta Movement," the author acts as a kind of ecclesial archeologist, seeking ways to explicate a doctrine of the church that is rather implicit. In the end we find that the ecclesiology is rather undeveloped, perhaps by design, in favor of more robust articulations of the salvific efficacy of Christ and the Holy Spirit, led by a charismatic figure with a small number of clergy, lay, and Khrist Bhakta support. Thus, the operative ecclesiology is remarkably Pentecostal and evangelical. Historically, the canonical, pakka-that is normative-progression into the Church begins with the catechumenate (the period of instruction into the Catholic faith), followed by baptism, and culminates in reception of the Eucharist. Yet because they do not receive baptism, they cannot be considered official members of the Church and thus cannot receive communion, "the core of the whole sacramental system" (259). Meanwhile, their piety suggests to Catholics, including Kuttiyanikkal, that they are, ironically, the most Christian, in a kind of simplified, pious, Hindu (often a rather vague signifier), early church kind of way. If they are not part of the Church, then who is?

The further one gets into the weeds of such discussions, the more one feels like the scholar is attempting to fit a square peg into a round hole. We find ourselves in a peculiar situation where there exist devotees of Christ, often more pious than baptized Catholics, who cannot fully participate in the Catholic Church as it is historically construed. This is because baptism is perceived as ipso facto breaking Hindu bonds (possibly evoking Hindu violence,) and because, surprisingly, Catholic clergy fear that baptizing these thousands would not only endanger themselves and the Khrist Bhaktas, but would actually lead these believers towards nominalism. This oftrepeated argument should give us pause. Kuttiyanikkal mentions such revelations, but fails to explore their profound implications.

Meanwhile, the author alludes to another body of Christians ready, willing, and able to afford Khrist Bhaktas full status, who suffer no scruples regarding precipitate baptism, and are only increasing in number. Should Khrist Bhaktas tire of being unable to receive the highest form of encounter with Yesu (as they have been taught that paramprasad, or Eucharist, represents), and if they should begin to perceive themselves as second-class citizens among baptized Catholics, then Pentecostals stand ready to accept them into their fold.

Unfortunately, the text lacks an index, but it does contain an exhaustive Table of Contents and a helpful system of transliteration for those unfamiliar with Hindi and Sanskrit. The robust footnotes are a treasure trove for those eager to attend to the author's sources, perhaps reaching their own unique conclusions. The dissertation is therefore a valuable contribution to ongoing reflection on a movement likely still in its early stages, and to issues of inculturation, Indian Catholicism, and the surprising intersection of bhakti, Catholic ashrams and charismatic Catholicism.

So can the Khrist Bhakta movement be a model for community building? The author is 
inconclusive. Perhaps this community is too idiosyncratic, the tradition too tied to structures and intransigent theologies born of different soil. We should note in closing that the challenges to Catholic ecclesiology are problems for the Indian Catholic Church, not necessarily for the Khrist Bhaktas. As is their wont, they continue to worship Yesu, Mata Mariayam and other saints as they are able, with all the Hindu/Christian/human tools at their disposal. They do so on terms often mediated by the Catholic Church in a charismatic, top-down, semi-acculturated register, but there is certainly no guarantee that this shall continue indefinitely.

Kerry P. C. San Chirico

Villanova University

\section{Ethnic Church Meets Megachurch: Indian American Christianity in Motion. By Prema A. Kurien. New York: New York University Press, 2017, xiv +279 pages.}

PREMA Kurien's Ethnic Church Meets Megachurch supplies the field with an important sociological account of the transnational religious and ethnic contestations within the Mar Thoma church, a Syrian Christian church based in Kerala. Her extensive ethnographic research, dating back to 1999 , is a refreshingly data-rich study that is longitudinally oriented in its inclusion of the extensive history of the Mar Thoma church since its inception in the early decades of the Christian era. It is also a geographically cross-sectional study in its attention to the transnational intersections between the Mar Thoma church in India and in the United States. Kurien's data reveals that research on religion and ethnicity in the United States must account for generational differences and specific nuances of a particular ethnic denomination's negotiations in multicultural America.

Most provocatively, Kurien's research demonstrates that second-generation Indian American Christians of the Mar Thoma church are decoupling ethnicity from religion by choosing to worship in multiracial, nondenominational evangelical Christian congregations. She reveals how they are adopting American evangelical ideals of "antitradition, antiliturgical, and individual worship orientation" (110) and centralizing the experience of personal salvation and the importance of proselytization. At times, one can almost hear Kurien mourning for the loss of a tradition-centric, liturgically heavy, Malayalam-based locus of support and community for immigrant Malayalee Christians (only 20-30 percent of the second and third generation attend the Mar Thoma church on a regular basis) (114). This is compounded by her legitimate fear that the second-generation millennials who are turning away from their parents' ethnic churches may lose the support system of the ethnic church that their parents built and become lost in "anonymous and impersonal gatherings" (243). However, this hint of lament is heavily veiled by Kurien's datadriven sociological account, which allows such generational fissures to exist in unresolved tension in their own voices derived from her extensive interviews and results in a substantive and enduring scholarly contribution.

Kurien's findings are quite anomalous in the field of ethnicity and religion in the United 